\title{
鋼橋の CFRP 板接着補修・補強の現状と課題 The Current Situation and Issues of Repair and Strengthening of Steel Bridges by Bonding CFRP Strips
}

\author{
石川 敏之* \\ Toshiyuki ISHIKAWA
}

\section{1.はじめに}

2007 年 6 月, 国道 23 号線の木曾川大橋のトラス斜材が 腐食により破断した。同年 8 月には, 国道 7 号線の本荘大 橋でも同様な部材の破断が生じた。さらに米国において， 2007 年 8 月に，鋼トラス橋が落橋した。このような状況 を受け，国内外を問わず，鋼橋の維持管理の重要性が再認 識されている。

鋼橋の補修・補強として, 例えば腐食による断面欠損を 補う場合，鋼板を，高力ボルトを用いて接合する工法が一 般に行われる。このような鋼板のボルト接合では，足場の 設置や接合作業に多大なコストと労力が掛かるため，大き な損傷が生じている場所のみに適用され，腐食損傷が小さ い場所は，再塗装を行う程度で，補修が行われない場合が ある。

これに対して，鋼部材の応力の低減あるいは断面欠損を 補うための簡易な補修・補強法として, 引抜成形された炭 素織維強化樹脂板 (CFRP 板) を接着する方法が提案さ れており，それに関する研究が盛んに行われている1 10)。 この工法では，CFRP 板が軽いため現場でのハンドリン グが良く，さらに接着作業に特別な機械や技能が必要ない ことなどの利点があるため，工事期間の大幅な短縮が可能 である11)。しかし，鋼橋の CFRP 板接着補修・補強の事 例はまだ少ない。これは，CFRP 板のはく離を防止する 設計法が確立されていないため，接着強度やその耐久性に 対する眯念がその要因の一つであると考えられる。

本稿では，国内外において実施された鋼橋の CFRP 板

\footnotetext{
*名古屋大学大学院 環境学研究科都市環境学専攻 愛知県名古屋市千種区不老町 † 464-8603

Department of Environmental Engineering and Architecture, Nagoya University

Furo-cho, Chikusa-ku, Nagoya, 464-8603, Japan
}

接着補修・補強の事例を紹介する。さらに, 鋼橋の CFRP 板接着補修・補強の設計に対する課題について述べる。

\section{2. 鋼橋の CFRP 板接着補修・補強の事例}

現在, CFRP 板接着による鋼橋の補修・補強は，国内 外で武験的に行われている。本章では, それらの事例およ び事前に実施された試験を紹介する。

\section{1 国内の事例}

我が国では，2002 年に宮城県の桜の目橋（図 1）におい て, 設計荷重の変更に伴って横桁が CFRP 板接着補強

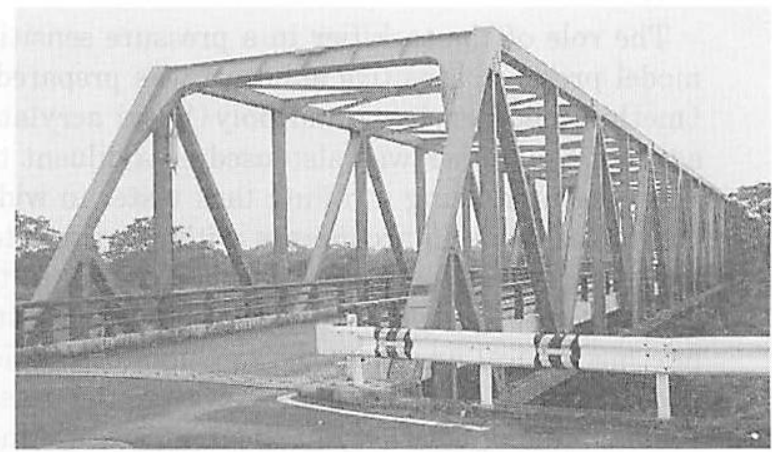

図 1 桜の目橋

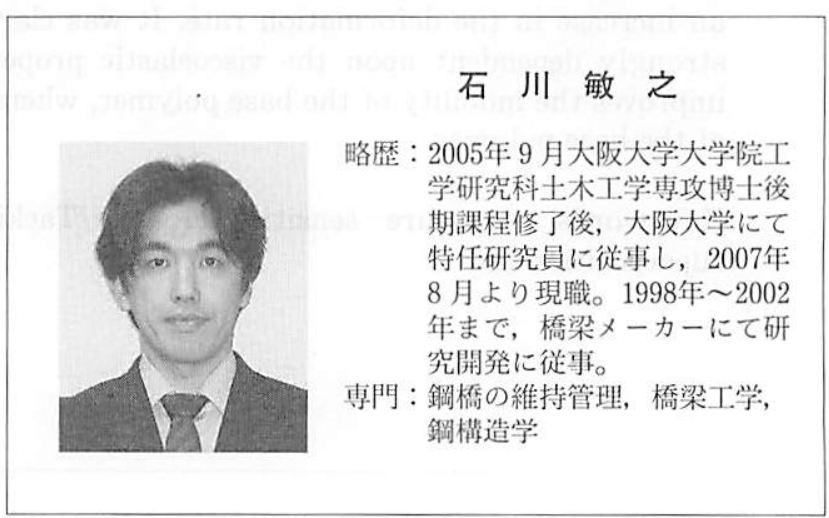




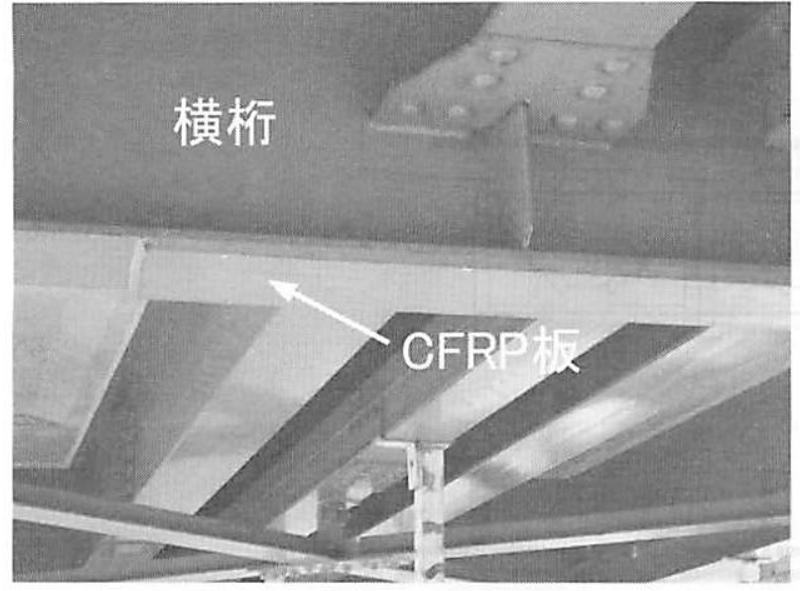

図 2 横林下フランジへの CFRP 板接着補強

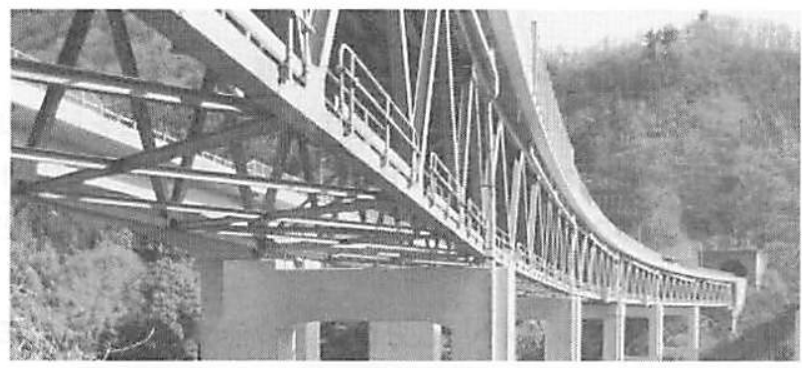

図 3 浅利橋

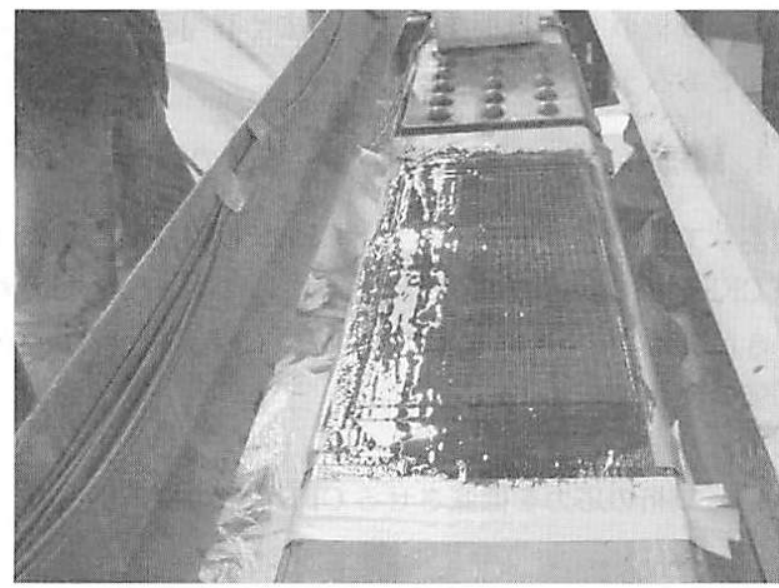

図 4 トラス下弦材の $\mathrm{CF}$ シート接着補修

されている ${ }^{11)}$ ここの橋では，横桁の下フランジ下面に幅 $200 \mathrm{~mm}$ ，長さ $2100 \mathrm{~mm}$ に渡って厚さ $1.2 \mathrm{~mm}$ ，ヤング率 $155 \mathrm{GPa}$ の CFRP 板が 10 枚接着され，24〜 48 時間の養生 後, 塗装が施されている。CFRP 板 10 枚は, 工場で積層 接着されている。補強された横析の下面を図 2 に示す。こ の橋の CFRP 板接着補強の設計を行うために，下フラン ジ下面に CFRP 板が接着された鋼桁の曲げ試験が行われ, 主桁の応力が CFRP 板と鋼桁を完全合成した場合の計算 值まで低減されていること，CFRP 板がはく離したとき の荷重が鋼桁の降伏荷重に達した後であることが確認され ている1)。

他方, 中央自動車道の浅利橋（鋼トラス橋：図 3）では,
トラス下防材の腐食による断面欠損を補うために，複数枚 の炭素織維シート (CF シート) 接着による補修が行われ ている ${ }^{12)}$ 。CF シート接着補修では，エポキシ樹脂を含浸 させながら複数枚の CF シートを部材に接着しているので, エポキシ樹脂の硬化後は, CFRP 板と同様な部材になる。 浅利橋では, トラス下弦材の上フランジとウェブへ，ヤン グ率 $640 \mathrm{GPa}$ ，換算厚さ $0.143 \mathrm{~mm}$ の $\mathrm{CF}$ シートが，腐食の 大きさに合わせて, CF シートの端が健全部になるように 適宜接着されている。CF シートの接着状況を図 4 に示す。 $\mathrm{CF}$ シート接着補修においても，CFRP 板接着と同様に鋼 部材の弾性範囲内ではく離が生じる場合があるため ${ }^{13)}$, 浅利橋の CF シート接着補修を行うために, CF シート接 着による鋼部材の応力の低減および，はく離に関する実験 が行われている ${ }^{12)}$ 。さらに，各 CF シートの端部を $25 \mathrm{~mm}$ ずらして接着することにより，端部を揃えた場合と比べて 接着剤に生じるせん断応力を低滅させる工夫を施している。

\section{2 海外の事例}

アメリカのデラウェア州において，プレートガーダー橋 の主桁の引張りを受ける下フランジの下面へ, 幅 $222 \mathrm{~mm}$ (幅 $37 \mathrm{~mm} \times 6$ 枚)，厚さ $5.25 \mathrm{~mm}$ ，ヤング率 $112 \mathrm{GPa}$ の CFRP 板接着補強が試験的に行われている ${ }^{14)}$ 。この橋では, 接着剂の荃生のために, CFRP 板が接着された析の直上 の車線のみ 8 時間，通行止めされている。また， CFRP 板之鋼桁との電解腐食を防止する目的で，CFRP 板と鋼 桁との間にガラス織維シート（GF シート）が挿入されて いる。奉橋の補強を行う前に, CFRP 板接着の耐久性を碓 認するために，引張りを受ける下フランジの下面に CFRP 板が接着された鋼桁の疲労試験が行われており，実際の橋 の下フランジに生じている程度の応力範网 $\Delta \sigma=34 \mathrm{MPa}$ を 1000 万回繰返し与えた後，鋼桁の弾性範囲内の荷重を 載荷して CFRP 板が力を担っていることが確認されてい る。さらに, CFRP 板接着鋼板の引張り疲労試験 $(\Delta \sigma=$ 82.5MPa で 255 万回繰返し載荷） 屯寒施され，CFRP 板 がはく離していない事が確認されている ${ }^{14)} 。$

アメリカのアイオワ州においても，プレートガーダー橋 の主林の引張りを受ける下フランジの上下面への CFRP 板接着補強が試験的に行われている ${ }^{15)}$ 。この橋では, ヤン グ率が $138 \mathrm{GPa}$ の CFRP 板を, 長さ $6.0 \sim 7.6 \mathrm{~m}$, 接着枚数 1〜3 枚および下フランジの下面（図 5 の左のパターン） のみあるいは上下面（図 5 の中央のパターン）へ接着する など，1つの橋で様々な CFRP 板接着の方法が試験的に 適用されている。施工完了後む, 環境による影響などの計 測が予定されている ${ }^{15)}$ 。

イギリスでは，ロンドンの地下鉄の Acton 橋（鉄道橋） の横桁下フランジ下面 (図 6 参照) への CFRP 板接着補 強が行われている ${ }^{16)}$ 。この橋では, 横杕が直接列車の荷重 

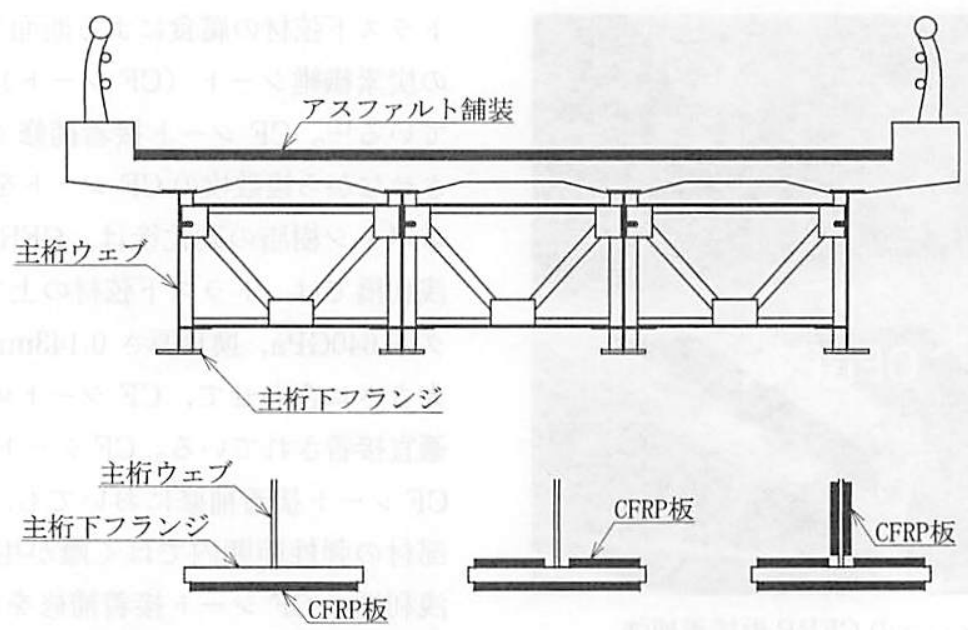

図 5 プレートガーダー橋の主桁への CFRP 板接着の例

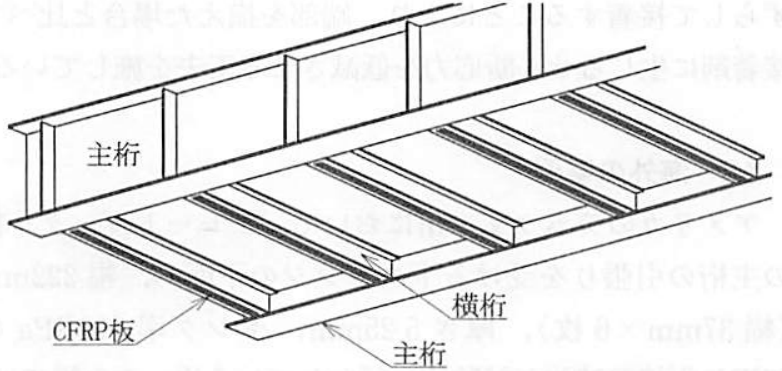

図 6 鉄道橋横桁への CFRP 板接着

を受ける部材になる。橋梁下面からの CFRP 板接着の利 点の一つとして, 通行止めを行わずに補修・補強できるこ とが挙げられる。Acton 橋では, 頻繁に列車が往来する ため, 列車を運行しながら CFRP 板が確実に接着される ことを検証するために, H 形鋼の下フランジに CFRP 板 を接着し, 養生中（24 時間以上）に $0.25 \mathrm{~Hz}$ で繰返し荷重 を与える試験を行っている ${ }^{16)}$

\section{CFRP 板接着補修の設計に対する課題}

第 2 章で紹介した CFRP 板接着補修・補強の事例では, 鋼桁と CFRP 板が完全に合成されている状態，すなわち 鋼桁と CFRP 板の完全合成理論により, 鋼桁の応力が所 定の值まで低減されるように，CFRP 板の材料選定およ び接着枚数が設計されている。CF シート接着でむ同様に, CF シートの材料および接着枚数を設計できる。さらに CFRP 板がはく離しないことを大型試験等によって確認 した後，実橋に適用されている。

しかし, 鋼桁の CFRP 板接着補修・補強では, 鋼桁の 断面力が接着剤のせん断力を介して CFRP 板へ伝達され る際, 断面力が部材の軸方向に沿って徐々に伝達される現 象（せん断遅れ現象）が生じるため, CFRP 板の端部近 傍において鋼析の応力が完全合成理論で与えられる值まで 低隇しない。さらに CFRP 板の接着箇所, 使用する接着 剤および接着面の状態によっては，鋼桁が降伏あるいは設
計荷重に達する前に CFRP 板がはく離する場合がある。 また，これまでの様に CFRP 板接着補修・補強を行う度 に, 鋼桁の応力の低減や CFRP 板のはく離強度を確認す るような実橋の補修・補強を再現した大型試験を行うこと は現実的ではない。

したがって，鋼部材の応力が設計の值まで低減される CFRP 板の接着長さを設計する方法，および CFRP 板が 設計荷重下ではく離しないように設計する方法の確立が, 今後, 鋼橋の CFRP 板接着補修が広く利用されるための 課題であろう。

\section{4. 鋼橋の CFRP 板接着補修・補強の設計}

本章では，第 3 章で述べた， CFRP 板の接着長さおよ び CFRP 板のはく離の防止について，これまでに行われ てきた研究の成果を踏まえて, 鋼桁の CFRP 板接着補修・ 補強の設計法について述べる。

\section{1 鋼桁の応力を低減させる CFRP 板の接着長さの 設計}

鋼析の下フランジの下面に CFRP 板が接着される場合 に対して, 図 7 に示す断面力のつり合いが, 鋼桁の断面力 が接着剂を介して CFRP 板へ伝達されるモデルとして用 いられる5,17,18)。すなわち，CFRP 板と鋼桁が断面力を受 け持ち，接着剤がせん断応力と垂直応力を受け持つと仮定 し，次式の鋼桁が分担する軸力 $N_{s}$ およびせん断力 $V_{s}$ に対 する微分方程式が導出される。

$$
\begin{aligned}
& \frac{d^{2} N_{s}}{d x^{2}}-c^{2} N_{s}=c^{2} \frac{K_{1}}{a} M+c^{2} \frac{K_{1} Z_{1}}{a^{2}} E_{s} I_{s}\left(\alpha_{s}-\alpha_{c}\right) \Delta T \\
& \frac{d^{4} V_{s}}{d x^{4}}+4 \omega^{4} V_{s}=\frac{4 \omega^{4}}{Z_{1}}\left[Q+J \frac{d N_{s}}{d x}\right]
\end{aligned}
$$

ここに, $c=\sqrt{b G_{e} a^{2} /\left(h E_{s} I_{s} Z_{1} K_{1}\right)}, K_{1}=1 /\left\{\left(r_{s} / a\right)^{2} Z_{1} Z_{2}+1\right\}$, 


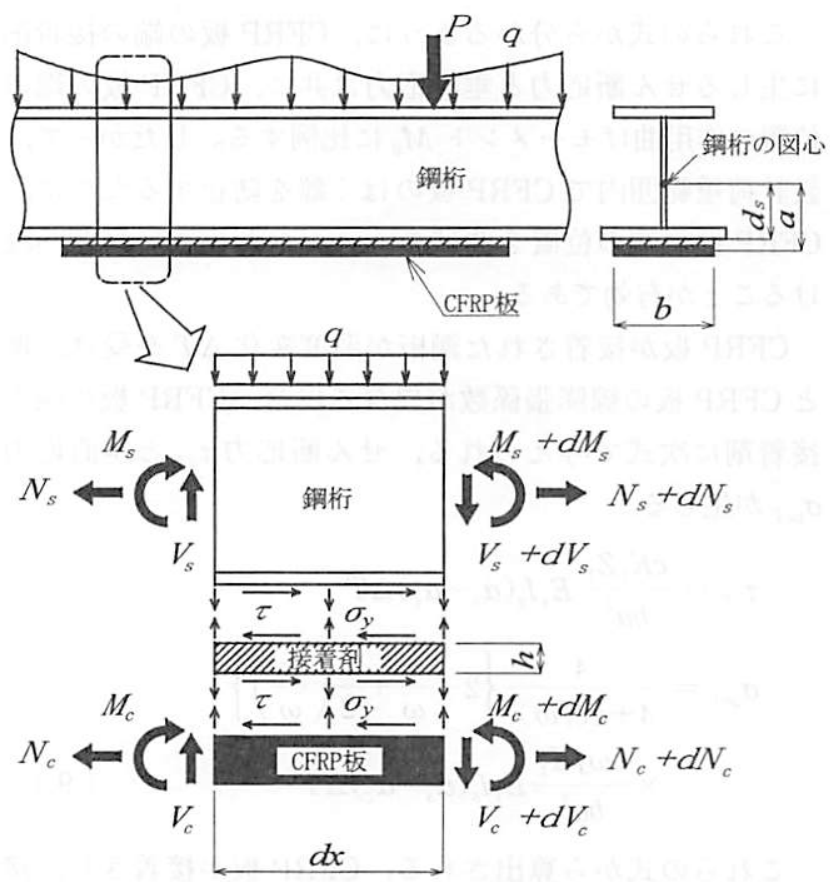

図 7 下フランジ下面に CFRP 板が接着された鋼析の 微小区間の力のつり合い

$r_{s}=\sqrt{I_{s} / A_{s}}, \quad Z_{1}=1+b t_{c}^{3} /\left(12 n I_{s}\right), Z_{2}=1+n A_{s} /\left(b t_{c}\right)$, $n=E_{s} / E_{c}, \quad \omega=1 / t_{c} \cdot \sqrt[4]{3 Z_{1} E_{e} t_{c} /\left(E_{c} h\right)}, \quad J=t_{c} / 2-$ $\left(Z_{1}-1\right) d_{s}, E_{s}, A_{s}, I_{s}$ : それぞれ, 鋼桁のヤング率, 断面 積および断面 2 次モーメント, $d_{s}$ : 鋼桁の中立軸から鋼桁 下フランジ下面までの距離, $E_{c}, t_{c}, b$ : それぞれ, CFRP 板のヤング率, 厚さおよび幅, $E_{e}, G_{e}, h:$ それぞれ, 接 着剂のヤング率, せん断弾性係数および厚さ, $a$ : 鋼桁と CFRP 板の図心間の距離， $\alpha_{s}, \alpha_{c}$ : それぞれ，鋼および CFRP 板の線膨張係数, $\Delta T:$ 温度変化量（温度上昇を正 とする), $M, Q: \mathrm{CFRP}$ 板が接着された鋼桁に生じる曲げ モーメントとせん断力。ただし，接着阂の厚さは鋼析の高 さや CFRP 板の厚さと比べて非常に小さいため, CFRP 板の図心間の距離を $a=d_{s}+t_{c} / 2$ としている。

境界条件を与えて, 式 (1) を解き, その解を式 (2) へ代 入して $N_{s}$ および $V_{s}$ が導出される。さらに次式から，鋼桁 が分担する曲げモーメント $M_{s}$ が与えられる。

$$
M_{s}=\frac{1}{Z_{1}}\left(M-N_{s} a\right)+\frac{1}{4 \omega^{4}} \frac{d^{3} V_{s}}{d x^{3}}
$$

このようにして尊出された鋼桁の分担断面力 $\left(N_{s}, V_{s}\right.$, $\left.M_{s}\right)$ の式には, 一般に, $\sinh (c l), \cosh (c l)$ あるいは $\tanh (c l)$ が含まれる。 $c l$ は, せん断遅れ現象を支配する パラメータであり, $c l$ の值がある一定以上になると鋼桁の 断面力が CFRP 板へ十分伝達される。したがって, CFRP 板の接着長さ $l_{\text {req }}$ は, 図 8 を参照して, 補修される部分の 長さ $l_{r}$ にせん断遅れ現象が生じている長さ $l_{s l}$ を付加して 次式で設計する必要がある。

$$
l_{\text {req }}=l_{r}+2 l_{s l}
$$

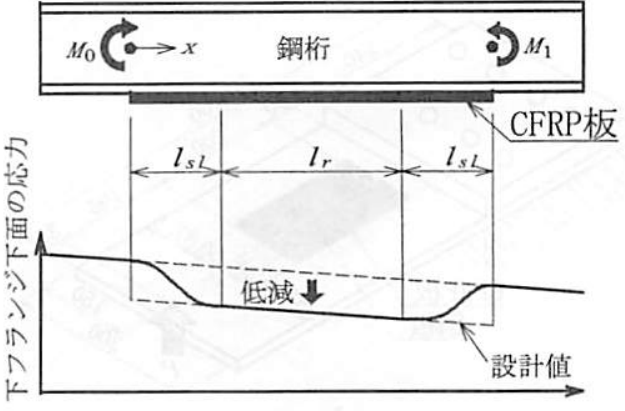

図 8 下フランジ下面の応力分布の概念図

ここに, $l_{r e q}: \mathrm{CFRP}$ 板の必要接着長さ, $l_{r}$ : 鋼析応力を 低減させる範囲, $l_{s l}=\zeta / c$ : せ九断遅れ現象によって鋼桁 応力が設計值まで低下しない範囲，ら：無次元パラメー夕。

鋼桁の断面力が CFRP 板へ十分伝達されるらの值は, 鋼桁, CFRP 板および接着剤の材料定数や寸法によって 異なるが, との值が 10 程度になると, 鋼析の応力がほぼ 設計值に収束する。ただし，CFRP 板が積層接着される 場合および複数の CF シートが接着される場合では, 各 $\mathrm{CFRP}$ 板間および各 CF シート間の接着䬉層においてもせ ん断遅れが生じるため, 安全率を含め, それらを考慮した との值を決定する必要がある。

\subsection{CFRP 板のはく離を防止する設計}

鋼桁, CFRP 板の弾性範囲内における CFRP 板のはく 離を防止する設計式として, 次式が提案されている ${ }^{19,20)}$ 。

$$
\frac{\sigma_{y e}}{2}+\sqrt{\left(\frac{\sigma_{y e}}{2}\right)^{2}+\tau_{e}^{2}} \leq \frac{\sigma_{p}}{\gamma}
$$

ここに， $\sigma_{y e}: \mathrm{CFRP}$ 板の端の接着剤に生じる垂直応力, $\tau_{e}: \mathrm{CFRP}$ 板の端の接着剤に生じるせん断応力, $\sigma_{p}$ : 接着 剤のはく離強度, $\gamma$ : 安全率。

式（5）は, CFRP 板の端の接着剤に生じる主応力があ る值に達したときにはく離すると仮定し, 安全率が考虑 された設計式である。著者は，図 9 に示す試験を行い, CFRP 板の端の接着剤に生じる垂直応力が, 圧縮になる場 合と引張りになる場合の両極端なケースに対して, CFRP 板がはく離（鋼板と CFRP 板の弾性範囲内）したときの CFRP 板の端の接着凪に生じる主応力（式 (5) の左辺) が 両者でほぼ同じになることを明らかにしている21,22)。した がって, 鋼桁と CFRP 板の弾性範囲内における CFRP 板 のはく離を防止する設計式として式 (5) が利用できると考 えられる。

Schnerch らは，実際に使用する材料および接着面の状 態を考虑した 1 面あるいは 2 面の引張りせん断接着強さの 結果を $\sigma_{p}$ に用いることを提案している。ただし， $\sigma_{p}$ の值 は, 繰返し荷重作用下や温度環境によっても変化すると考 えられるので 23,24), 実際に適用される条件に合わせて, $\sigma_{p}$ の值を与える試験方法やその設計值を明らかにし，適切な 


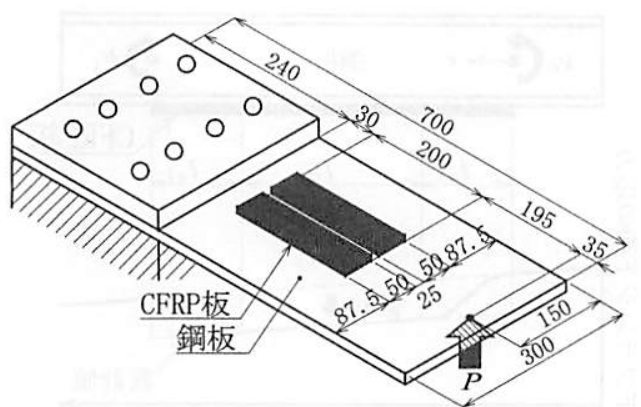

（a）試験体の寸法
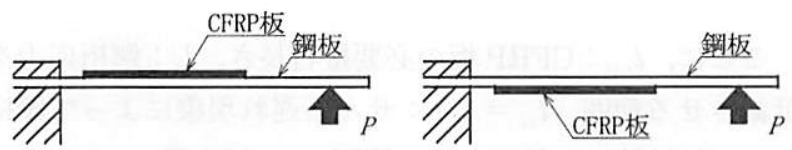

（b） $\sigma_{y e}$ が圧縮の場合

（c） $\sigma_{y e}$ が引張りの場合

図 $9 \mathrm{CFRP}$ 板接着鋼板の板曲げ試験

安全率 $\gamma$ を設ける必要がある。

CFRP 板が接着された鋼桁では, 接着剤に生じるせん断 応力と垂直応力は, 両者ともに CFRP 板の端で最大になる。 例えば, 図 8 に示すようなモーメント $M_{0}, M_{1}\left(M_{0} \geq M_{1}\right)$ が作用し，CFRP 板の接着長さが式 (4) を満足する程度に 長い場合, CFRP 板の端の接着剤に生じるせん断応力 $\tau_{e}$ と 垂直応力 $\sigma_{y e}$ の最大值は, $M_{0}$ が作用している側 $(x=0)$ に生じ, それぞれ次式で与えられる。

$$
\begin{aligned}
\tau_{e}= & \left\{1-\frac{1-M_{1} / M_{0}}{c l_{\text {req }}}\right\} \frac{c K_{1}}{b a} M_{0} \\
\sigma_{y e}= & {\left[\frac{4}{4+(c / \omega)^{4}}\left\{2-\frac{c}{\omega}+\frac{1}{2}\left(\frac{c}{\omega}\right)^{3}\right\}\right.} \\
& +2\left\{\left(\frac{\omega}{c}-\frac{1-M_{1} / M_{0}}{c l_{\text {req }}}\right)\left(Z_{1}-1\right) \frac{a}{J K_{1}}\right. \\
& \left.\left.+\frac{1-M_{1} / M_{0}}{c l_{\text {req }}}\right\}\right] \frac{c \omega J K_{1}}{b a Z_{1}} M_{0}
\end{aligned}
$$
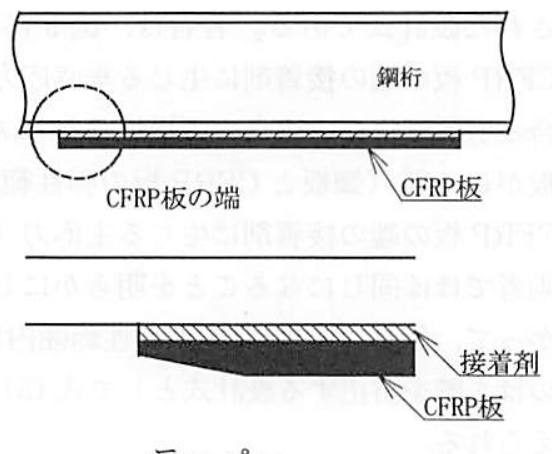

テーパー

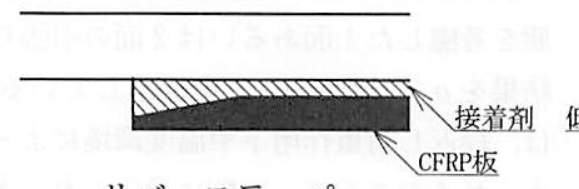

リバーステーパー
これらの式から分かるように，CFRP 板の端の接着剤 に生じるせん断応力と垂直応力は共に, CFRP 板の端の 位置の作用曲げモーメント $M_{0}$ に比例する。したがって, 設計荷重範囲内で CFRP 板のはく離を防止するために, CFRP 板の端の位置を曲げモーメントが小さい範囲へ設 けることが有効である。

CFRP 板が接着された鋼桁が温度変化 $\Delta T$ を受け，鋼 と CFRP 板の線膨張係数が異なる場合, CFRP 板の端の 接着剤に次式で与えられる, 世ん断応力 $\tau_{e T}$ と垂直応力 $\sigma_{y e T}$ が生じる。

$$
\begin{aligned}
\tau_{e T}= & \frac{c K_{1} Z_{1}}{b a^{2}} E_{s} I_{s}\left(\alpha_{s}-\alpha_{c}\right) \Delta T \\
\sigma_{y e T}= & \frac{4}{4+(c / \omega)^{4}}\left\{2-\frac{c}{\omega}+\frac{1}{2}\left(\frac{c}{\omega}\right)^{3}\right\} \\
& \times \frac{c \omega J K_{1}}{b a^{2}} E_{s} I_{s}\left(\alpha_{s}-\alpha_{c}\right) \Delta T
\end{aligned}
$$

これらの式から算出される, CFRP 板が接着され，接 着㶡が硬化したときからの温度変化によって生じる $\tau_{e T}$ と $\sigma_{y e}$ む, 式 (5) の CFRP 板のはく離を防止する設計の際 に考虑する必要がある。

他方, 図 10 に示すような CFRP 板の端にテーパーやス テップを設けること ${ }^{20,25,26)}$, CFRP 板よりあ剛性の小さな ガラス繊維シート (GF シート) を $\mathrm{CFRP}$ 板と鋼桁の間に 挿入すること ${ }^{7)}$, ならびに CFRP 板の端近傍のみに低弾 性の接着剤を塗布すること ${ }^{9,26)}$ などの接着阂に生じる応 力を低隇させる工法の適用も，CFRP 板のはく離を防止 するためには有効である。

\section{5. まとめ}

本稿では，鋼橋の簡易な補修・補強法として期待されて いる CFRP 板接着の適用事例の紹介と, CFRP 板接着補
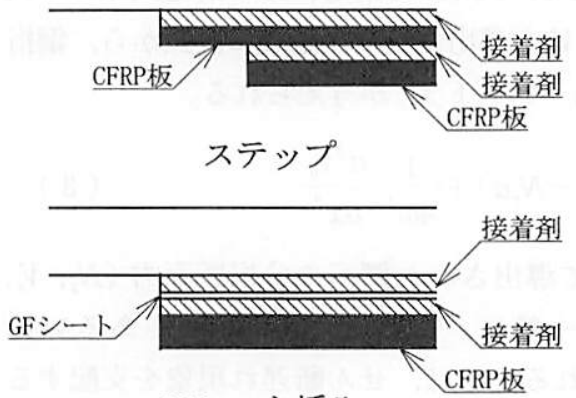

GFシート挿入

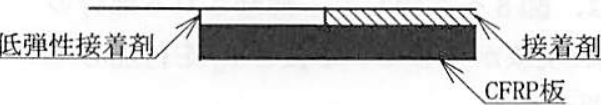

低弾性接着風の利用

図 $10 \mathrm{CFRP}$ 板の端の接着剤に生じる応力を低滅させる工法 
修・補強の課題とその設計法について言及した。現在, 鋼 橋の CFRP 板接着補修・補強は, まだ試験的に行われて いる段階で, その実例は少ない。しかし, 今後, 補修・補 強が必要になる鋼橋が増加すると予想されているので, 比 較的簡易にそして施工期間の短縮が可能になる CFRP 板 接着が適用されると考えている。

\section{謝辞}

首都大学東京の中村一史先生, 並びに日鉄コンポジット (株) の小林朗氏に, 実橋への CFRP 板接着の適用事例の写 真をご提供頂いた。ここに記して謝意を表します。

\section{参 考 文 献}

1）渡邊憲市，板垣一也，鈴木博之，鋼構造年次論文報告集，8， $679(2000)$

2）鈴木博之, 永崎央陽, 遠藤勇一, 池田圭一, 鋼構造年次論 文報告集，8，683(2000).

3) R. Sen, L. Liby and G. Mullins, Composites: Part B, 32, Issue 4, 309 (2001).

4）野阪克義, 金子大咋, 古川喬朗, 鈴木研二, 西出 靖, 鋼 構造論文集, 10, No. 38, 61 (2003).

5) J. Deng, M. M. K. Lee, S. S. J. Moy, Composite Structures, 65, 205(2004).

6）中村一史, 諸井敬嘉, 鈴木博之, 前田研一, 入部孝夫, 鋼 構造年次論文報告集, 13, 89 (2005).

7）石川敏之, 大倉一郎, 喜多伸明, 構造工学論文集, 52A, 1317 (2006).

8）姜 威, 中村一史, 鈴木博之, 前田研一, 入部孝夫, 鋼構 造年次論文報告集， 14，595（2006）。

9）石川敏之, 西田貴裕, 大倉一郎, 横田季彦, 斉藤 誠, 構造 工学論文集, $54 \mathrm{~A}, 842$ (2008).

10）松村政秀, 北田俊行, 久部修弘, 構造工学論文集, 54A, 834 (2008).
11）板垣一也，渡邊憲市，鈴木博之，第 8 回鋼構造の補修・補強 技術報告論文集，49，(2002）。

12）杉浦 江, 大坦賀津雄, 稲葉尚文, 富田芳男, 長井正嗣, 小 林 朗, 第 7 回複合構造の活用に関するシンポジウム論文 集, 56-1 (2007).

13）杉浦 江, 大垣賀津雄, 長井正嗣, 小林 朗, 第 6 回複合構 造の活用に関するシンポジゥム論文集，48-1（2005）.

14) T. C. Miller, M. J. Chajes, D. R. Mertz and J.N.Hastings, Journal of Bridge Engineering, 6, Issue 6, 514 (2001).

15) B. M. Phares and T.J.Wipf, Proceedings of the 2003 Mid - Continent Transportation Research Symposium, (2003).

16) S. S. J. Moy and A. G. Bloodworth, Structures \& Buildings, 160, Issue SB2, 81 (2007).

17) S. T. Smith, J. G. Teng, Engineering Structures, 23, 857 (2001).

18）西田貴裕 - 石川敏之 · 大倉一郎, 土木学会第 62 回年次学術 講演会概要集 第 1 部, 62, 535 (2007).

19) J. Deng, M. M. L. Lee, Composite Structures, 78, 222 (2007).

20) D. Schnerch, M. Dawood, S. Rizkalla and E. Sumner, Construction and Building Materials, 21, 1001 (2007).

21）石川敏之, 佐々木裕, 山田健太郎, 日本接着学会第 46 回年 次大会講演要旨集, 213 (2008)

22）石川敏之, 佐々木裕, 山田健太郎, 応用力学論文集, 11, 903 (2008).

23）山谷佑介, 姜 威, 中村一史, 前田研一, 鈴木博之, 入部孝 夫, 伊原啓裕, 土木学会第 63 回年次学術講演会概要集 第 1 部, 63, 931 (2008).

24) M. Bocciarelli, P. Colombi, G. Fava and C. Poggi, Composite Structures, 83, 334 (2009).

25) J. Deng and M. M. K. Lee, Composites: Part B, 39, 731 (2008).

26）小村啓太, 石川敏之, 大倉一郎, 横田季彦, 斉藤 誠, 土木 学会第 62 回年次学術講演会概要集 第 1 部, 62, 537 (2007).

27) M. D. Fitton and J. G. Broughton, International Journal of Adhesion \& Adhesives, 25, 329 (2005). 